\title{
Dos presidentes bajo la mirada del dibujante satírico: el caso de la caricatura política y sus recursos en dos producciones de Francia y Argentina
}

\author{
Two presidents under the gaze of the satirical cartoonist: the \\ case of the political cartoon and its resources in two \\ productions from France and Argentina
}

Ana Pedrazzini $^{1}$

RESUMEN

A partir de una metodología que articula análisis cualitativos y cuantitativos, realizamos un estudio bicultural sobre los recursos lingüísticos e ícono-plásticos que intervienen en el proceso de producción de sentido en la prensa satírica. Para ello, analizamos 248 caricaturas políticas de una y varias viñetas que refieren a la figura presidencial de Jacques Chirac (1995-2007) y Carlos Menem (1989-1999) en el semanario satírico francés Le Canard enchaîné y el suplemento argentino Sátira/12 $2^{2}$ respectivamente, durante dos períodos de gran trascendencia política: inicio del primer mandato y reelección de cada presidente. El análisis de la representación visual de los personajes así como de las figuras retóricas verbales y visuales utilizadas indica una tendencia similar en ambos periódicos, lo cual da indicios a favor de la existencia de un sistema de procedimientos satírico-humorísticos en común, transculturales, operando en la caricatura política.

\footnotetext{
${ }^{1 *}$ Universidad Nacional del Comahue - CONICET.

**Esta investigación fue apoyada por CONICET (PIP 112200080101029), Agencia Nacional de Promoción Científica y Tecnológica (PICT 06-1607) y por la Universidad Nacional del Comahue (B139).

2 "Agradecemos a los periódicos y dibujantes de Le Canard enchaîné y Sátira/12 el permitirnos la publicación de las caricaturas que acompañan el presente artículo".
} 


\section{ABSTRACT}

By articulating qualitative and quantitative analyses, we have made a bicultural study of linguistic and icono-plastic devices participating in the production of meaning in the satirical press. Therefore we have analyzed 248 political cartoons and strips which refer to presidents Jacques Chirac (1995-2007) and Carlos Menem (1989-1999) in the French satirical weekly Le Canard enchaîné and the Argentinean weekly newspaper supplement Sátira/12 respectively, during two periods of great political importance: the beginning of their first presidential term, and re-election. The analysis of their visual representation, as well as the verbal and visual rhetorical figures used, indicate a similar tendency in both newspapers. From these results we may refer the existence of a common satirical-humoristic system composed of transcultural devices operating in the political cartoon.

Keywords: Semio-linguistics. Political cartoon. Satirical press. Humour. Rhetorical figures.

Lejos estamos de considerar a la caricatura política, como hiciera Boyer de Nîmes en la época de la revolución francesa, "el termómetro de la opinión" (DUPRAT, 2002). Y sin embargo esta imagen mixta e híbrida, que conjuga lo verbal y lo visual, la información y la opinión (PEDRAZZINI; SCHEUER, 2010), sigue teniendo una gran vigencia. Una actualidad palpable a partir de diferentes acontecimientos que pusieron sobre el tapete el debate en torno a la libertad de prensa y de expresión, desde la serie de caricaturas en las que se representó a Mahoma en un periódico danés, originando protestas violentas en el mundo árabe (SEURRAT, 2008), hasta, de forma más limitada y cercana, la calificación de "mensaje cuasi-mafioso" por parte de la presidenta argentina Cristina Fernández, al referirse a una caricatura del dibujante Hermenegildo Sábat ${ }^{3}$.

Desde hace más de dos siglos, la caricatura política se ha ocupado de desacralizar el poder de las jerarquías, presentando una mirada deformada de la actualidad política, cuestionando y denunciando, con irreverencia y humor, abusos y excesos. Desde los regímenes monárquicos hasta los sistemas presidenciales o parlamentarios, el jefe de Estado - o su equivalente - ha sido el blanco predilecto de los ataques verbales y visuales de los autores satíricos.

En este estudio nos proponemos realizar un análisis pormenorizado y sistemático sobre los componentes discursivos en la caricatura política que toma como blanco al Presidente de la Nación. ¿Qué recursos son puestos en juego en la representación de la figura presidencial en la caricatura política? ¿Qué lugar ocupa lo verbal y lo visual en este tipo de representaciones? ¿Cuáles son los recursos más explotados y cuáles los menos útiles para los fines satíricos de la caricatura política? ¿En qué se asemejan y en qué se diferencian estos recursos en caricaturas de países diferentes? Tomando todas estas preguntas como marco de reflexión, proponemos un aparato teórico-metodológico para desarrollar un estudio comparativo sobre los recursos

\footnotetext{
${ }^{3}$ Ver sobre este tema los artículos publicados en La Nación, Clarín y Página/12 el 2, 3 y 4 de abril de 2008.
} 
lingüísticos e ícono-plásticos ${ }^{4}$ detectados en caricaturas de dos periódicos que pertenecen a culturas diferentes.

\section{La caricatura política como discurso satírico}

La utilización general y confusa que se ha hecho coloquialmente de la expresión caricatura política nos lleva, en primera instancia, a presentar ciertos elementos de definición.

Del italiano caricare, caricaturizar significa cargar, "dar peso [...] o relieve, apretar o insistir, exagerar" (TILLIER, 2005, p. 15). A esta acepción más vinculada al campo de la pintura, se añade posteriormente una connotación más belicosa de caricare (cargar un arma de fuego) y la metáfora que presenta la caricatura como "un arma capaz de herir" se cristaliza. Esta concepción de la caricatura obedece al lugar indiscutido que cumple y ha cumplido a lo largo de los siglos en el terreno de la sátira política. La finalidad satírica de la caricatura se evidencia a partir de la articulación de lo cómico y la ofensa, caracterizándose por un espíritu crítico y de denuncia, orientado hacia la descalificación de la clase política, y particularmente de los gobernantes.

El término caricatura política utilizado en nuestro estudio responde a un sentido amplio puesto que conjuga características más netamente formales con cuestiones de contenido. Desde el plano formal, pone énfasis en la representación gráfica exagerada, deformada y ridiculizada de personas o situaciones, acentuando o disminuyendo rasgos del rostro -con mayor frecuenciao del cuerpo. Desde el plano más ligado al contenido, la caricatura política se centra en ciertos aspectos en detrimento de otros en el tratamiento de hechos de actualidad, y por lo tanto, presenta inherentemente una visión particular sobre los mismos. Esto quiere decir que la burla, la ridiculización, no se aplican únicamente a personas sino también a situaciones y acciones. De acuerdo con Tillier, consideramos que toda caricatura política opera a partir de la "exageración, deconstrucción y alteración" de la realidad abordada (TILLIER, 2005, p. 20). La mirada del dibujante es selectiva y comprometida puesto que más que dar cuenta, busca desenmascarar y denunciar los vicios y excesos.

Hiperbólica por naturaleza, la representación que se hace en toda caricatura conjuga a la vez la simplicidad, la economía de los elementos y la semejanza con respecto al objeto representado. El dibujante de caricaturas políticas manifiesta una particular capacidad de

${ }^{4}$ En relación a los signos icónicos y plásticos, ver GRUPO $\mu, 1992$. 
condensar la información y realizar análisis en ocasiones muy finos, a partir de unos pocos trazos y unos pocos elementos. $\mathrm{Al}$ mismo tiempo, debe garantizar una semejanza cierta con la persona representada, de forma tal que no peligre su identificación. Estas características son la base de los procedimientos de esquematización y de experimentación descritos por Ernst Gombrich (1984). Recorriendo la historia del desarrollo de la caricatura, muy estrechamente ligada a los estudios de experimentación de la fisonomía, de lo bello y de lo feo en maestros de la pintura como Leonardo Da Vinci y los hermanos Carraci, Gombrich sitúa la esquematización como el resultado de un proceso de simplificación creciente, solamente posible sobre la base de complejidades anteriores. La experimentación, por su parte, se desarrolla por el interés que los artistas depositan, ya no sólo en referentes externos, sino también en sus propias creaciones, en la puesta en escena de las mismas (STEIMBERG, 2001). En este sentido, la caricatura se acerca a otras formas risibles, que hacen del lenguaje el objeto de los juegos que elaboran.

Dentro de la prensa satírica, existe otro tipo de dibujo al que también se aplican las características hasta ahora presentadas para la caricatura política: la tira, compuesta generalmente, de tres a seis viñetas. Esta imagen cuenta con la posibilidad de incorporar secuencias narrativas al tratamiento que se hace de un sujeto dado mediante el uso de viñetas, las cuales se suceden las unas a las otras para asegurar una coherencia temporal y espacial. Sintética como la caricatura, la tira despliega un continuum a partir de algunos elementos esenciales, y es el lector, gracias a sus competencias lingüísticas, icónicas y plásticas, quien va a reconstruir estas secuencias de forma tal de ver ese continuo (ECO, 2008).

\section{Estudios multiculturales sobre el humor y sus procedimientos}

En 1988, Avner Ziv coordinó un libro multicultural sobre el humor, interesándose en aquellos factores que pueden ser considerados como universales o más ligados a una cultura en particular. Este autor concibe el humor como un mensaje social que como tal, cumple ciertas funciones, utiliza determinadas técnicas, presenta un contenido y es usado en ciertas situaciones. Postula que los dos primeros aspectos son más bien universales mientras que los otros dos varían según las culturas. Así, con respecto al área que nos compete, el de los procedimientos humorísticos, afirma:

[...] la incongruencia, la sorpresa y la lógica local (esto es, algo que parece lógico en cierto contexto) son los elementos principales en 
todo humor. Estos son elementos cognitivos, y como los procesos cognitivos son universales (como lo son los fisiológicos involucrados en la risa y la sonrisa), no hay razones para esperar diferencias nacionales o culturales. ${ }^{5}$

En cuanto a las funciones del humor, como expresión de agresividad, mecanismo de defensa, control social (BERGSON, 1924) o desafío intelectual, Ziv plantea que si bien son universales, las mismas pueden estar influenciadas por la historia de cada cultura. Así, los contenidos sexuales parecen ser una vieja tendencia en el humor francés pero son escasos en el humor belga; el humor inglés presenta una mayor proporción de aspectos intelectuales que el yugoslavo, etc. Este autor sugiere que las mayores diferencias interculturales podrían estar dadas por las situaciones en las que se hace uso y se considera apropiado el uso del humor. En el marco de este trabajo, nos interesaremos sobre la participación de lo particular y lo universal en los procedimientos humorísticos.

Un antecedente más reciente de estudios multiculturales proviene de un grupo de investigadores de Francia y España que se interesó en el uso del humor en los medios y cuyos avances constituyen el dossier de la revista Questions de communication número 10. Entre los trabajos más afines al nuestro, las autoras Houdebine-Gravaud y Pozas (2006), realizaron un análisis cualitativo de los contenidos discursivos (temas, situaciones, blanco), procedimientos y efectos en recepción identificados en un corpus constituido por 35 dibujos de prensa publicados en diarios de Francia y España en torno al ataque del 11 de septiembre de 2001. Otro estudio centrado sobre el uso del humor en las crónicas de la prensa cotidiana de ambos países logró identificar diferencias entre los dos contextos culturales (FERNÁNDEZ; VIVERO GARCÍA, 2006). Mientras que el blanco en Francia recae en el otro, el poder, el adversario; en España es uno mismo o la esfera política y económica. Los autores se interesaron en los procedimientos enunciativos que dan cuenta de la distancia existente entre el periodista y el enunciador discursivo e implican una toma de postura del primero con respecto a su enunciado, al blanco y a su público. Así, detectaron que la ironía es un recurso más característico de las crónicas francesas en tanto que lo que más abunda en los textos españoles es el sarcasmo. Si la ironía puede ser rápidamente definida como el hecho de decir lo contrario a lo que uno quiere dar a entender, quedando la intención real oculta (volveremos sobre ella más abajo), el sarcasmo adopta una postura más explícita y agresiva. En términos de Patrick Charaudeau (2006), esta figura opera a partir de una "hiperbolización de lo negativo".

\footnotetext{
${ }^{5}$ Las citas textuales que se presentan en este trabajo de obras publicadas en otros idiomas han sido traducidas por la autora. Frase original citada: "Incongruity, surprise, and local logic (i.e., something that seems logical in a certain context) are the main elements in all humor. These are cognitive elements, and since cognitive processes are universal (as are the physiological ones involved in laughter and smiling), there are no reasons to expect national or cultural differences"; ZIV, 1988, x.
} 
Las figuras retóricas adquieren particular relevancia en producciones humorísticas, entre las cuales situamos a la caricatura política, puesto que constituyen la base del juego con palabras; de la asociación insólita, incongruente de dos o más ideas; de procedimientos enunciativos que juegan con lo implícito; de la repetición; por citar algunos de los recursos más habituales. En el apartado siguiente nos abocaremos a definir lo que entendemos por figura retórica y nos explayaremos en los grupos de figuras existentes.

\section{Las figuras retóricas, recursos centrales en la caricatura política}

Partiendo del supuesto de que todo enunciado puede ser expresado de manera simple y directa, la figura retórica es una operación que permite pasar de un lenguaje propio a un lenguaje figurado, haciendo coexistir un sentido literal y aparente con un sentido latente. Según la definición de Georges Molinié (1993, p. 113), "hay figura en un enunciado cuando, para el receptor, el efecto de sentido producido no se reduce a aquél normalmente instaurado por la simple combinación léxico-sintáctica de este enunciado" ${ }^{6}$

La figura retórica ha sido tradicionalmente concebida como la trasgresión de una norma del lenguaje, del mundo físico, de la lógica, la moral, la sociedad, etc. Esta concepción ha sido criticada por diversos autores, en parte porque han puesto en duda la pertinencia de la noción de norma, que sería un modelo teórico y artificial (FROMILHAGUE, 1995). No obstante, la misma sigue siendo útil desde un punto de vista analítico y explicativo.

De las cinco grandes áreas que comprende la retórica -inventio, dispositio, elocutio, memoria y actio-, la elocutio se ocupa de evaluar cuáles son los recursos estilísticos más aptos para seducir a la audiencia. Lejos de ser meramente ornamentales, las figuras retóricas juegan un rol importante en la estrategia argumentativa de los discursos.

La clasificación de las figuras retóricas se presenta como una labor ardua y compleja, no sólo por la gran cantidad existente sino también por las controversias que el hecho de clasificarlas ha suscitado a lo largo de los siglos. Una propuesta interesante es la de Georges Molinié (1993), quien distingue entre figuras microestructurales y figuras macroestructurales. Las primeras pueden identificarse y aislarse en el texto puesto que están ligadas a la materialidad de los elementos formales del discurso. Las segundas, en cambio, no pueden identificarse ni aislarse porque afectan el sentido de todo un enunciado haciendo intervenir el contexto amplio del discurso.

\footnotetext{
${ }^{6}$ Frase original citada: « il y a figure, dans un énoncé, quand, pour le récepteur, l'effet de sens produit ne se réduit pas à celui qui est normalement engagé par le simple arrangement lexico-syntaxique de cet énoncé ».
} 
La clasificación más consensuada o tradicional distingue cuatro grupos de figuras que se centran sobre los niveles semánticos, lógicos, sintácticos y pragmáticos de las frases. Los cuatro grupos de figuras comprenden las figuras de sentido, los tropos y otras figuras que sirven para enriquecer la o las significaciones de una palabra al utilizarlas en un contexto inesperado (ROBRIEUX, 1993); las figuras de palabras, basadas en juegos léxicos y sonoros; las figuras de pensamiento, que refieren a la relación del enunciado con el sujeto, el orador, y con su objeto, el referente (REBOUL, 1993); y las figuras de construcción, por último, centradas en la sintaxis y el orden de las palabras.

Catherine Fromilhague (1995, p. 20) advierte sobre la caducidad de esta tetrapartición, puesta en evidencia por las investigaciones actuales que muestran a la vez la interdependencia de los niveles en los cuales intervienen las figuras y la dimensión transfrástica de estas últimas. Elige no obstante mantener esta clasificación destacando el continuum que articula las estructuras fonográficas, sintácticas, semánticas y referenciales, postura que haremos también nuestra.

La clasificación que adoptamos para nuestro estudio es una adaptación de aquella propuesta por Beth y Marpeau (2005). Está compuesta por ocho grupos, los cuales fueron concebidos en función de la importancia fundamentalmente cuantitativa de los tipos de figuras detectados en los corpus analizados (Tabla 1). Esta clasificación nos permite analizar tanto lo lingüístico como lo ícono-plástico, con ligeras modificaciones en este último caso. La pertinencia de una retórica aplicada a la imagen fue postulada ya hace décadas por, entre otros, Roland Barthes (1964), Dominique Durand (1970) y el Grupo $\mu$ (1992).

Con respecto a las modificaciones efectuadas en lo ícono-plástico, descartamos las figuras de palabras e incluimos al símbolo (en su acepción retórica) dentro del grupo de las metáforas fijas por la alta presencia que tiene en lo visual y por su carácter convencional. Cabe además precisar que dada la tan elevada presencia en el lenguaje visual de la hipérbole plástica de rostros y cuerpos, la sinécdoque (en la que una parte representa al todo) y la metonimia del signo, las mismas no fueron consideradas en nuestro corpus puesto que no contribuían a captar matices de interés para nuestro análisis. En el caso de la hipérbole plástica, porque la caricatura opera a través de la exageración y la deformación física del objeto representado, y en el de la sinécdoque, porque es una característica habitual la de representar en la imagen una parte para dar cuenta del todo. En cuanto a la metonimia de signo, la misma puede ser definida como una figura en la cual un referente abstracto es representado a través del objeto que lo emblematiza en una cultura dada (FROMILHAGUE, 1995). Se trata, como dice la autora, de metonimias materializantes. Nosotros extendemos esta acepción para incluir toda representación de lo gestual que busca transmitir sentidos previamente codificados y compartidos en una cultura dada, tales como el enojo, "materializado" a través del ceño fruncido, o la sorpresa, convencionalmente representada a través de la boca abierta. 
Tabla 1 - Clasificación de las figuras retóricas utilizadas en nuestro estudio.

\begin{tabular}{|c|c|c|}
\hline \multicolumn{2}{|c|}{ TIPOS DE FIGURAS } & DESCRIPCIÓN \\
\hline \multicolumn{2}{|c|}{ Figuras de palabras } & $\begin{array}{l}\text { Centradas en la sonoridad, modificación y creación de } \\
\text { palabras: asonancia, neologismo, metaplasmo, } \\
\text { acrónimo, geminación, etc. }\end{array}$ \\
\hline \multicolumn{2}{|c|}{ Figuras de contigüidad } & $\begin{array}{l}\text { Tropos que transfiere el sentido entre términos } \\
\text { asociados en una misma isotopía. Metonimia, } \\
\text { sinécdoque y figuras relacionadas. }\end{array}$ \\
\hline \multirow[t]{2}{*}{$\begin{array}{l}\text { Figuras de } \\
\text { asociación }\end{array}$} & $\begin{array}{l}\text { Metáforas fijas } \\
\text { y lexicalizadas }\end{array}$ & $\begin{array}{l}\text { Metáfora no creativa, banalizada por el uso. } \\
\text { La metáfora es un tropos que introduce una ruptura } \\
\text { de isotopía. }\end{array}$ \\
\hline & $\begin{array}{l}\text { Metáforas } \\
\text { creativas }\end{array}$ & $\begin{array}{l}\text { Metáfora (in praesentia, in absentia, etc.), oxímoron, y } \\
\text { figuras relacionadas. }\end{array}$ \\
\hline \multicolumn{2}{|c|}{ Figuras de doble sentido } & $\begin{array}{l}\text { Trabajan con la polisemia del lenguaje. Calambur, } \\
\text { silepsis, juego de palabras, y figuras relacionadas. }\end{array}$ \\
\hline \multicolumn{2}{|c|}{ Figuras de construcción } & $\begin{array}{l}\text { Se centran en la simetría, oposición, acumulación, } \\
\text { repetición, disposición y desestructuración de las } \\
\text { palabras: antítesis, paralelismo, elipse, repetición, } \\
\text { entre otras. }\end{array}$ \\
\hline \multirow{2}{*}{$\begin{array}{l}\text { Figuras de } \\
\text { pensamiento }\end{array}$} & $\begin{array}{l}\text { Ironía y sus } \\
\text { variantes }\end{array}$ & Ironía, antífrasis, sarcasmo. \\
\hline & $\begin{array}{l}\text { Otras figuras } \\
\text { de } \\
\text { pensamiento }\end{array}$ & $\begin{array}{l}\text { Se centran en la intensidad y dialéctica de las figuras: } \\
\text { hipérbole, lítote, personificación, alusión, paradoja y } \\
\text { figuras relacionadas. }\end{array}$ \\
\hline
\end{tabular}

Fonte: O Autor.

En este estudio no pretendemos dar cuenta de manera total y exhaustiva de las figuras presentes en las imágenes, lo cual nos parece irrealizable dada la inagotable riqueza del lenguaje figurado. Hemos buscado, no obstante, realizar un estudio sistemático y riguroso, definiendo las figuras retóricas y especificando los criterios considerados para su análisis. En ciertos casos, aplicamos un control interjuez que facilitó el reconocimiento de determinadas figuras y verificó su identificación. En el apartado de resultados presentaremos ejemplos de algunas de ellas, acompañados de definiciones de aquellas figuras menos conocidas o de particular relevancia. 


\section{Instrumentos metodológicos y procedimiento para el armado de un estudio comparativo}

El objetivo principal de este trabajo es el de analizar los recursos puestos en juego en las caricaturas políticas que refieren a la figura presidencial, haciendo hincapié en la representación visual que se hace de los personajes y en las figuras retóricas, tanto visuales como verbales, utilizadas.

Como parte de una investigación más amplia, este estudio está atravesado por una hipótesis que lo trasciende, según la cual proponemos pensar en un sistema común de procedimientos satírico-humorísticos verbales y visuales identificables en producciones satíricas pertenecientes a países diferentes. Retomamos así el debate académico en torno a la universalidad y particularidad del humor aunque más que "universal" como hace Avner Ziv (1988), preferimos hablar de "humor transcultural". Presuponemos que hay elementos que traspasan las fronteras y otros que son exclusivamente locales. Si como proponemos, existe un sistema de procedimientos en común, es esperable no obstante identificar diferencias en el peso que los mismos tienen en un periódico determinado y particularmente, en aspectos más estrechamente ligados al contenido.

Teniendo presente dicho marco general de reflexión, este trabajo adopta una perspectiva bicultural limitándose a dos estudios de caso, centrados en dos periódicos de Francia y Argentina y en dos presidentes.

\section{Delimitación del corpus}

Los periódicos estudiados presentan grandes diferencias, en particular ligadas a la historia y al status periodístico de cada uno. Le Canard enchaîné surgió en 1915 como reacción a la cobertura periodística que se hacía durante la Primera Guerra Mundial, y es el periódico satírico francés más longevo. Es un semanario de ocho páginas que no depende de ningún medio periodístico ni anunciante publicitario y se destaca además por su extensa red de informantes y su larga tradición en el periodismo de investigación. Sátira/12 es un suplemento semanal de cuatro páginas que pertenece al diario argentino Página/12. El matutino y su suplemento fueron creados en 1987, cuatro años después de la vuelta a la democracia en la Argentina. Con sus tapas irreverentes, cargadas de humor, sátira e ironía, en las que la imagen cobra un lugar central; el tratamiento de temas innovadores (ULANOVSKY, 1997); y el desarrollo de investigaciones periodísticas focalizadas en develar casos de corrupción, Página/12 pronto se instauró como un caso de ruptura en la prensa argentina (PEDRAZZINI, 2007). Hoy en día, el suplemento Sátira/12 es el periódico satírico-humorístico más antiguo del período post-dictadura en ese país. Estas diferencias no invalidan nuestro objetivo de estudiar los procedimientos satírico-humorísticos 
de uno y otro periódico y de hecho podrían dar más fuerza a resultados que indiquen una convergencia en los mismos.

Carlos Menem (1989-1999) y Jacques Chirac (1995-2007) son dos personalidades coetáneas de una larga carrera política, reelegidos como Presidentes y en el poder durante una decena de años.

Nuestro corpus está constituido por todas las caricaturas políticas de una (234) o más viñetas -tiras- (14) en las que se representa a los presidentes Carlos Menem y Jacques Chirac respectivamente en Sátira/12 y Le Canard enchaîné. Tomamos dos períodos de análisis equivalentes para ambos casos: tres meses al inicio del primer mandato y tres meses que comprenden la campaña de reelección y el comienzo del segundo mandato. En total consideramos 15 ejemplares del periódico argentino y 17 del periódico francés. Este recorte da una homogeneidad temporal y en parte temática a las caricaturas analizadas.

Debido al bajo número de tiras que forman parte de nuestro corpus, en este trabajo no haremos una diferenciación entre la caricatura política de una o varias viñetas.

\section{Articulación cuali y cuantitativa del estudio}

El diseño de este estudio bicultural de producciones satíricas incluyó cuatro etapas diferentes pero estrechamente vinculadas, que articularon métodos cualitativos y cuantitativos: elaboración de un sistema de dimensiones y categorías de análisis, análisis discursivo, análisis de contenido y análisis estadístico. La lógica comparativa, inherente a este estudio, intervino en diferentes estadios de la investigación.

En primera instancia, partimos de una matriz de análisis destinada a la descripción, el análisis y la interpretación de los signos ícono-plásticos y lingüísticos presentes en las caricaturas acordes con una perspectiva semio-lingüística. Cada caricatura es considerada como un texto, es decir, como un todo discursivo coherente que responde a ciertas reglas sintácticas en sus estrategias de comunicación (VILCHES, 1984). Este enfoque apunta a estudiar los diferentes procedimientos puestos en juego por los periódicos para producir sentido. Además de una perspectiva semio-lingüística, adoptamos un enfoque retórico-estilístico, que pone especial énfasis en las figuras retóricas, consideradas como recursos clave en los discursos satíricos, tal como hemos planteado más arriba.

El diseño del sistema de dimensiones y categorías de análisis adoptó un proceso deductivo o inductivo, según las dimensiones en cuestión, es decir que partió de la teoría para llegar a los datos o viceversa. Un ejemplo del primer caso es la clasificación aplicada a las figuras 
retóricas, que es una adaptación de la corriente tradicional, y más particularmente, de la propuesta de Axelle Beth y Elsa Marpeau (2005). En el segundo caso se encuentran la mayor parte de las dimensiones referidas a la representación visual del personaje, como la postura del cuerpo o las acciones realizadas. La construcción del sistema de dimensiones y categorías debe ser entendida como un proceso dialéctico, caracterizado por reajustes y reformulaciones, que implicaron una estrecha interacción entre los análisis discursivos y de contenido.

Los diferentes signos ícono-plásticos y lingüísticos presentes en las caricaturas fueron clasificados, codificados y cuantificados según el sistema de categorías, apuntando a la búsqueda de regularidades e incluso de invariantes en el análisis, es decir, de elementos que constituyan una constante en los corpus considerados. En este trabajo daremos cuenta de cuatro grupos de dimensiones. Una de ellas está más relacionada con aspectos de contenido: los personajes representados; mientras que las otras refieren a aspectos formales: la representación visual del personaje presidencial (se trata de una macro-dimensión que comprende siete dimensiones), el contexto de representación, y las figuras retóricas visuales y verbales (número y tipos detectados por imagen). La Tabla 2 que figura en la sección de resultados presenta la totalidad de categorías que comprende cada dimensión. A la excepción de las figuras retóricas -que pueden intervenir de forma conjunta en un mismo texto-, todas las dimensiones son mutuamente excluyentes.

Este trabajo de sistematización y cuantificación aportó un panorama del peso o la importancia que cada categoría tiene en el corpus. La aplicación de tests estadísticos (chicuadrado y residual estandarizado) en la cuarta etapa, permitió analizar el grado de asociación o de dependencia entre las variables o dimensiones e identificar aquellas categorías que se alejan de la norma. La estadística utilizada para testear la hipótesis de independencia entre dos variables evalúa el grado de divergencia entre las frecuencias observadas y las frecuencias esperadas bajo la presuposición de independencia. El estadístico obtenido tiene una distribución chi-cuadrado, lo que hace posible conocer qué probabilidad tiene de alcanzar un valor determinado. Si dicha probabilidad es muy baja, también lo será la probabilidad de que la hipótesis sea verdadera. Para nuestros cálculos, elegimos un p-valor (valor de probabilidad por debajo del cual consideramos la hipótesis como falsa) igual o inferior a 0,01. El cálculo del residual estandarizado también toma como punto de partida las frecuencias observadas y esperadas y hace posible detectar qué categorías se encuentran sobre o sub-representadas con respecto a las demás.

\section{Resultados}

El análisis plurietápico de las 248 caricaturas políticas de una o más viñetas permitió captar tendencias generales de comportamiento de las distintas dimensiones consideradas y 
establecer patrones de similitud o diferencia entre el corpus francés y el argentino. La Tabla 2 presenta la distribución, expresada en porcentajes, de la totalidad de dimensiones y categorías consideradas para las imágenes del Canard enchaîné (CE) y Sátira/12 (S/12). La columna de la derecha señala si la distribución es similar o diferente luego de la aplicación del chi-cuadrado e indica el p-valor cuando éste es inferior a 0,01. Las celdas coloreadas informan los casos de subrepresentación, en negrita, (es decir aquellos que están por debajo de la norma) y los de sobrerepresentación, subrayados, (por encima de la norma). Dichos datos fueron obtenidos a partir del cálculo del residual estandarizado.

\section{Personajes dibujados}

Antes de explayarnos en los recursos elegidos por cada periódico para construir una mirada satírica en torno a Jacques Chirac y Carlos Menem, es interesante observar quién o quiénes son representados con estos personajes presidenciales pues en la mayoría de los casos se encuentran acompañados. Como es de esperar con aquellas dimensiones más estrechamente ligadas al contexto $-\mathrm{y}$ acorde con resultados anteriores, la dimensión sobre los personajes representados presenta grandes diferencias entre un periódico y el otro. Por el contrario, las dimensiones centradas en aspectos más formales presentan relativamente poca variabilidad, es decir que tienden a ser similares.

En prácticamente una de cada tres caricaturas políticas francesas, Jacques Chirac aparece solo contra $9 \%$ en el caso argentino y en $13 \%$ el presidente francés está con su Primer Ministro, mientras que en ninguna de las imágenes Carlos Menem aparece con su Vice-Presidente ${ }^{7}$. Esto puede estar relacionado con el hecho de que comparativamente, el poder ejecutivo del que dispone el Primer Ministro en Francia -como Jefe de Gobierno- es más fuerte que el del VicePresidente en Argentina. Por otro lado, la relación entre el Presidente y su Primer Ministro y el grado de dominación y subordinación de uno y otro es objeto de numerosas caricaturas de nuestro corpus francés, como se puede apreciar en la Figura 1a; sobre la cual nos detendremos más abajo.

Si los dibujantes del Canard enchaîné tienden a representar una mayor variedad y cantidad de personajes junto al presidente -sea políticos o civiles-, los autores de Sátira/12 optan por uno o dos individuos, de los cuales se destacan los colaboradores y asesores políticos y los periodistas. La alta presencia de asesores que rodean al Presidente Menem pone el énfasis en la necesidad del personaje de tener la opinión y los consejos de sus allegados tanto en torno a la toma de decisiones como a la eficacia de sus acciones. Por otro lado, una de cada cuatro imágenes

\footnotetext{
${ }^{7}$ Cabe aclarar que en uno de los seis meses analizados este puesto estuvo vacante.
} 
presentan a Carlos Menem siendo entrevistado o dando una conferencia de prensa, resultado muy en sintonía con el perfil altamente mediático del político. En este sentido, el especialista en sociología política Luis Alberto Quevedo (1999, p. 215) asegura que Menem "hizo del contacto con los periodistas un lazo permanente de su vínculo con la sociedad, produciendo una comunicación basada en la preeminencia de la imagen y no en la fuerza de la palabra".

Tabla 2 - Distribución de las dimensiones y categorías de análisis consideradas en las 248 caricaturas políticas de una o más viñetas analizadas en Le Canard enchaîné(CE) y Sátira/12 $(\mathrm{S} / 12)$.

\begin{tabular}{|c|c|c|c|c|}
\hline DIMENSIÓN DE ANÁLISIS & CATEGORÍAS DE ANÁLISIS & CE & $\mathrm{S} / 12$ & $\begin{array}{l}\text { DISTRIBUCIÓN DE } \\
\text { AMBOS CORPUS }\end{array}$ \\
\hline \multicolumn{5}{|c|}{ PERSONAJES REPRESENTADOS } \\
\hline \multicolumn{2}{|l|}{ Chirac/ Menem solo } & $30 \%$ & $9 \%$ & \multirow{11}{*}{ DIFERENTE $(\mathrm{p}<0.005)$} \\
\hline \multicolumn{2}{|c|}{ Con Primer Ministro/Vice-Presidente } & $13 \%$ & $0 \%$ & \\
\hline \multicolumn{2}{|c|}{ Con aliados políticos } & $8 \%$ & $13 \%$ & \\
\hline \multicolumn{2}{|l|}{ Con adversarios políticos } & $6 \%$ & $4 \%$ & \\
\hline \multicolumn{2}{|l|}{ Con gobernantes extranjeros } & $3 \%$ & $7 \%$ & \\
\hline \multicolumn{2}{|l|}{ Con la familia } & $8 \%$ & $0 \%$ & \\
\hline \multicolumn{2}{|l|}{ Con ciudadanos } & $6 \%$ & $11 \%$ & \\
\hline \multicolumn{2}{|l|}{ Con periodistas } & $1 \%$ & $24 \%$ & \\
\hline \multicolumn{2}{|l|}{ Con colaboradores, asesores } & $4 \%$ & $27 \%$ & \\
\hline \multicolumn{2}{|c|}{ Con personajes políticos y no políticos (categoría mixta) } & $14 \%$ & $0 \%$ & \\
\hline \multicolumn{2}{|l|}{ Con otros personajes } & $4 \%$ & $4 \%$ & \\
\hline \multicolumn{5}{|c|}{ REPRESENTACIÓN VISUAL DEL PERSONAJE } \\
\hline \multirow[b]{2}{*}{ ACCIONES } & Pasivas & $19 \%$ & $9 \%$ & \multirow{2}{*}{ SIMILAR } \\
\hline & Activas & $81 \%$ & $91 \%$ & \\
\hline \multirow[b]{2}{*}{ GESTOS } & Formales & $75 \%$ & $91 \%$ & \multirow{2}{*}{ SIMILAR } \\
\hline & Informales & $25 \%$ & $9 \%$ & \\
\hline \multirow{5}{*}{$\begin{array}{l}\text { ACTIVIDADES } \\
\text { REALIZADAS }\end{array}$} & Jugar, actuar & $21 \%$ & $29 \%$ & \multirow{5}{*}{ SIMILAR } \\
\hline & Trabajar & $55 \%$ & $67 \%$ & \\
\hline & $\begin{array}{l}\text { Entretenerse/informarse } \\
\text { (consumo medios) }\end{array}$ & $4 \%$ & $2 \%$ & \\
\hline & Descansar/comer & $9 \%$ & $0 \%$ & \\
\hline & Otras & $11 \%$ & $2 \%$ & \\
\hline \multirow{4}{*}{ POSTURA DEL CUERPO } & $\begin{array}{l}\text { Acciones enérgicas : caminar, } \\
\text { correr, volar, etc. }\end{array}$ & $7 \%$ & $18 \%$ & \multirow{4}{*}{ SIMILAR } \\
\hline & Estar parado & $59 \%$ & $49 \%$ & \\
\hline & Estar sentado, acostado & $25 \%$ & $22 \%$ & \\
\hline & Otras & $8 \%$ & $11 \%$ & \\
\hline \multirow{4}{*}{$\begin{array}{l}\text { EXPRESIONES FACIALES } \\
\text { DE EMOCIONES }\end{array}$} & Serio & $40 \%$ & $69 \%$ & \multirow{4}{*}{ DIFERENTE $(\mathrm{p}<0.01)$} \\
\hline & Sonriente & $30 \%$ & $16 \%$ & \\
\hline & Sorprendido & $6 \%$ & $0 \%$ & \\
\hline & Enojado & $9 \%$ & $0 \%$ & \\
\hline
\end{tabular}




\begin{tabular}{|c|c|c|c|c|}
\hline & $\begin{array}{l}\text { Inquieto, incómodo, con } \\
\text { miedo }\end{array}$ & $9 \%$ & $9 \%$ & \\
\hline & Otras & $6 \%$ & $7 \%$ & \\
\hline \multirow{5}{*}{ ACCIÓN VERBAL } & Hablar, gritar (solo) & $55 \%$ & $27 \%$ & \multirow{5}{*}{ DIFERENTE $(\mathrm{p}<0.005)$} \\
\hline & Dialogar & $14 \%$ & $44 \%$ & \\
\hline & Escuchar & $14 \%$ & $7 \%$ & \\
\hline & Reflexionar, pensar & $2 \%$ & $2 \%$ & \\
\hline & Otras & $14 \%$ & $20 \%$ & \\
\hline \multirow{4}{*}{ VESTIMENTA } & Vestimenta formal de trabajo & $78 \%$ & $78 \%$ & \multirow{4}{*}{ SIMILAR } \\
\hline & Vestimenta informal & $8 \%$ & $18 \%$ & \\
\hline & $\begin{array}{l}\text { Vestimenta fantasiosa, } \\
\text { ficticia }\end{array}$ & $11 \%$ & $2 \%$ & \\
\hline & Otras & $3 \%$ & $2 \%$ & \\
\hline \multicolumn{5}{|c|}{ CONTEXTO DE REPRESENTACIÓN } \\
\hline \multicolumn{2}{|c|}{ Despacho presidencial, sala de trabajo, Casa de Gobierno } & $18 \%$ & $22 \%$ & \multirow{7}{*}{ DIFERENTE $(\mathrm{p}<0.01)$} \\
\hline \multicolumn{2}{|l|}{ Radio, TV, sala de conferencia } & $4 \%$ & $13 \%$ & \\
\hline \multicolumn{2}{|l|}{ Casa, lugar de vacaciones } & $8 \%$ & $0 \%$ & \\
\hline \multicolumn{2}{|l|}{ Contexto ficticio o fantasioso } & $1 \%$ & $0 \%$ & \\
\hline \multicolumn{2}{|l|}{ Otro contexto } & $8 \%$ & $11 \%$ & \\
\hline \multicolumn{2}{|l|}{ Aire libre } & $8 \%$ & $20 \%$ & \\
\hline \multicolumn{2}{|l|}{ Ausente } & $51 \%$ & $33 \%$ & \\
\hline \multicolumn{5}{|l|}{ FIGURAS RETÓRICAS } \\
\hline \multirow{7}{*}{$\begin{array}{l}\text { FIGURAS RETÓRICAS } \\
\text { ÍCONO-PLÁSTICAS }\end{array}$} & Figuras de contigüidad & $5 \%$ & $8 \%$ & \multirow{7}{*}{ SIMILAR } \\
\hline & 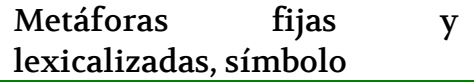 & $17 \%$ & $12 \%$ & \\
\hline & $\begin{array}{l}\text { Metáforas creativas y otras } \\
\text { figuras de asociación }\end{array}$ & $45 \%$ & $32 \%$ & \\
\hline & Figuras de doble sentido & $2 \%$ & $0 \%$ & \\
\hline & Figuras de construcción & $10 \%$ & $16 \%$ & \\
\hline & Ironía y variantes & $6 \%$ & $4 \%$ & \\
\hline & $\begin{array}{l}\text { Otras figuras de } \\
\text { pensamiento }\end{array}$ & $17 \%$ & $28 \%$ & \\
\hline \multirow{4}{*}{$\begin{array}{c}\text { CANTIDAD DE FIGURAS } \\
\text { ÍCONO-PLÁSTICAS POR } \\
\text { IMAGEN }\end{array}$} & Una sola figura & $24 \%$ & $22 \%$ & \multirow{4}{*}{ SIMILAR } \\
\hline & Dos figuras & $11 \%$ & $11 \%$ & \\
\hline & Tres o cuatro figuras & $2 \%$ & $4 \%$ & \\
\hline & Ninguna figura & $63 \%$ & $62 \%$ & \\
\hline \multirow{8}{*}{$\begin{array}{l}\text { FIGURAS RETÓRICAS } \\
\text { LINGÜÍSTICAS }\end{array}$} & Figuras de palabras & $6 \%$ & $2 \%$ & \multirow{8}{*}{ DIFERENTE $(\mathrm{p}<0.005)$} \\
\hline & Figuras de contigüidad & $2 \%$ & $0 \%$ & \\
\hline & $\begin{array}{l}\text { Metáforas fijas } \quad \text { y } \\
\text { lexicalizadas }\end{array}$ & $7 \%$ & $2 \%$ & \\
\hline & $\begin{array}{l}\text { Metáforas creativas y otras } \\
\text { figuras de asociación }\end{array}$ & $10 \%$ & $13 \%$ & \\
\hline & Figuras de doble sentido & $14 \%$ & $7 \%$ & \\
\hline & Figuras de construcción & $16 \%$ & $12 \%$ & \\
\hline & Ironía y variantes & $25 \%$ & $20 \%$ & \\
\hline & $\begin{array}{l}\text { Otras figuras } \\
\text { pensamiento }\end{array}$ & $20 \%$ & $45 \%$ & \\
\hline \multirow{4}{*}{$\begin{array}{l}\text { CANTIDAD DE FIGURAS } \\
\text { LINGÜÍSTICAS POR } \\
\text { IMAGEN }\end{array}$} & Una sola figura & $48 \%$ & $31 \%$ & \multirow{4}{*}{ SIMILAR } \\
\hline & Dos figuras & $27 \%$ & $27 \%$ & \\
\hline & Tres o más figuras & $14 \%$ & $20 \%$ & \\
\hline & Ninguna figura & $12 \%$ & $22 \%$ & \\
\hline
\end{tabular}




\title{
Representación visual de los personajes presidenciales
}

En cuanto a la representación visual de los personajes, en cinco de las siete dimensiones se observa un comportamiento similar. Sus acciones son considerablemente más activas que pasivas -es decir que los personajes intervienen de manera directa y voluntaria en la realización de una acción- y sus gestos son formales, enmarcándose dentro de los esperados en un Presidente. Los gestos informales, como tener las manos en los bolsillos, sobre las caderas o apoyadas contra un mueble, intervienen de forma más puntual. Los personajes pasan la mayor parte del tiempo parados, en una de cada cuatro imágenes están sentados o acostados y en el caso de Carlos Menem, en 18\% de los caricaturas se encuentra realizando una acción enérgica (contra sólo 7\% en las caricaturas de Jacques Chirac). Esto se explica por la participación del Presidente argentino en un partido de fútbol solidario al inicio de su primer mandato -cubierto reiteradamente por Sátira/12-, al que siguieron eventos similares. Bajo la gestión de Carlos Menem, la expresión de "espectacularización o farandulización de la política" cobró todo su sentido. Al respecto, Quevedo (1999, p. 215) afirma:

\begin{abstract}
Menem hizo su irrupción en la televisión de formas inesperadas: jugando al fútbol, cantando, participando en una mesa de café, bailando tangos, etc. Es decir, no usaba los medios para hablar de política, sino que establecía un contacto con la gente y hacía política desde los medios hablando 'de otra cosa', apareciendo en lugares inesperados, casi como alguien que pertenece al mundo del espectáculo y no que llega desde otro espacio de poder.
\end{abstract}

Pasemos ahora a la vestimenta con la que se dibuja a los personajes. La misma suele ser bastante tradicional, siendo idéntico el porcentaje obtenido para los casos en los que aparecen con traje, camisa y corbata (78\%). El 18\% de las caricaturas en las que el "Carlos Menem" de Sátira/12 está vestido con equipo deportivo guarda estrecha relación con su participación en eventos deportivos. El hecho de dibujar a los presidentes con vestimenta ficticia para abordar temas de la actualidad política es bastante excepcional, siendo un poco más usual en Le Canard enchaîné (ver, por ejemplo, Figura 1a). La misma puede ser completamente fantasiosa, como el traje de super héroe; anacrónica como una toga romana; o bien puede ser ficticia al no corresponder con la ocupación del personaje ni con las actividades que podría ejercer.

A continuación nos detendremos en las dos dimensiones que presentan una distribución estadísticamente diferente: las expresiones faciales de las emociones y las acciones verbales. En 
cuanto a la primera de ellas, cabe señalar la poca expresividad del personaje argentino, tanto porque en el $69 \%$ de los casos está serio como por el hecho de que comparativamente, la dimensión presenta menos diversidad que en el periódico francés. Esto da cuenta del poco recurso que los autores de Sátira/12 hacen de este tipo de representación, que puede ser fuertemente portadora de sentido. Jacques Chirac, en cambio, aparece serio o sonriente, enojado ante los resultados de una medida poco eficaz, inquieto por los casos de malversación de fondos que lo rodean, sorprendido por los comentarios políticos de su esposa Bernadette o por las preguntas de los periodistas, por citar algunos de los casos más recurrentes.

En la dimensión que refiere a la acción verbal del personaje presidencial, observamos una inversión entre las dos categorías más habituales: hablar (solo) y dialogar. En la primera sólo se atribuye un globo a Jacques Chirac o a Carlos Menem mientras que en la segunda tanto éstos como los individuos que los acompañan intervienen con algún enunciado, a forma de diálogo. Al cruzar esta dimensión con la que da cuenta de los personajes representados, encontramos algunos elementos que nos permiten interpretar esta inversión: en el 30\% de las caricaturas el presidente francés aparece solo en tanto que en la mitad de las caricaturas argentinas, Carlos Menem responde preguntas de los periodistas o intercambia opiniones con sus colaboradores.

El cruce de la dimensión que refiere a los personajes dibujados también nos aporta información para interpretar el contexto de representación. Eso ocurre en el caso de la sobrerepresentación de las salas de conferencia en las imágenes de Sátira/12 o de la casa o lugar de vacaciones en el que se dibuja a Jacques Chirac, quien aparece en $8 \%$ de las caricaturas con su mujer -su par argentino no aparece nunca dibujado con su familia en el corpus analizado. La representación, por encima de la norma, de Carlos Menem al aire libre guarda relación, en parte, con su participación en eventos deportivos. Sin embargo, de todas las categorías, la ausencia de contexto es la más recurrente en ambos corpus, particularmente en el francés, en el que la mitad de las caricaturas no presentan un escenario. Queda claro que este recurso no es indispensable para reconocer la situación representada o transmitir un mensaje. Hemos señalado anteriormente que una de las características de la caricatura política y de forma más extensiva, del dibujo de prensa, es la economía en la representación, de forma tal que el lector pueda entender rápidamente el mensaje. En este sentido el dibujante Pati, de Sátira/12, -al que entrevistamos en el marco de nuestra investigación- insiste sobre la necesidad de dibujar sólo lo que es afín al mensaje humorístico y satírico que se quiere transmitir puesto que un dibujo demasiado cargado de detalles puede distraer. En los talleres de humor gráfico que regularmente dicta suele preguntarles a sus alumnos: “¿Qué están buscando? ¿Un buen dibujo o un buen chiste?".

Hemos visto hasta aquí el comportamiento de las dimensiones que hacen referencia a los personajes y escenarios dibujados así como a la representación visual del personaje presidencial. A partir de los datos obtenidos, cabe reflexionar en torno al status de las dimensiones y 
categorías consideradas. Hicimos una distinción inicial entre dimensiones de contenido y de forma: las primeras están estrechamente ligadas al contexto, es decir, a la temática de actualidad tratada; las segundas, en cambio, forman parte de los recursos o procedimientos utilizados por el dibujante para transmitir un mensaje a la vez crítico y humorístico en torno a un hecho determinado. Dentro de la macro-dimensión que refiere a la representación visual del personaje, hay categorías en las que los límites entre el contenido y la forma son poco claros: representar al personaje enojado o inquieto por una situación real, mirando un programa de televisión sobre el cual se pronunció públicamente, etc. Apelar a la representación de situaciones ficticias y fantasiosas, como disfrazar a los políticos de romanos o luchadores galácticos, por el contrario, es claramente un recurso opcional del dibujante, que da prueba de la creatividad puesta en juego para abordar los acontecimientos políticos. Este tipo de procedimientos tienen un alto valor y a menudo densidad semiótica e interpelan directamente al lector, quien debe actualizar un bagaje cultural amplio, que poco o nada tiene que ver con el hecho noticioso. Dentro de la variedad de recursos "prescindibles" también podemos mencionar el hecho de dibujar a los dirigentes con las manos en los bolsillos, con pijama, corriendo -exceptuando los casos en los que los políticos son conocidos por su actividad deportiva. Las figuras retóricas también son recursos claramente formales, que juegan un rol central en las caricaturas políticas, por su potencial para agradar, conmover, instruir: el "placere, docere, movere" de Cicerón.

\section{Las figuras retóricas en lo visual y en lo verbal}

El análisis comparativo entre las caricaturas del Canard enchaîné y Sátira/12 puso en evidencia una notable proximidad entre las figuras más y menos características de ambos periódicos. De hecho, sólo en una de las cuatro dimensiones estudiadas relativas a la cantidad y al tipo de figuras retóricas detectadas por imagen se encontró una diferencia estadísticamente significativa.

El uso de figuras retóricas verbales es mucho más frecuente que el de figuras visuales en ambos corpus: mientras que un poco más de una de cada dos caricaturas presentan figuras íconoplásticas (0,55 para Sátira/12 y 0,51 para Le Canard enchaîné), el número promedio de figuras lingüísticas es de 1,33 en ambos periódicos. La densidad de figuras es también más alta en lo verbal, donde los casos de dos, tres o más figuras por imagen alcanzan porcentajes más altos (más de $40 \%$ contra sólo $15 \%$ en las figuras visuales). A estos datos también se suma una mayor variedad de figuras lingüísticas que ícono-plásticas, como se puede observar en las Figuras 3 y 4. 
Del conjunto de figuras visuales, la metáfora aparece como el recurso más solicitado por los dibujantes del Canard enchaîné y de Sátira/12, aquél que les permite establecer analogías a menudo insólitas, cómicas, críticas. Este es el caso de la Figura 1a, en la que la nominación de Alain Juppé como Primer ministro por Jacques Chirac, apenas asume en 1995, es presentada como una entrega de diplomas. La crítica no es hacia el Presidente, quien se encuentra en relación de superioridad, sino hacia Alain Juppé, caracterizado como un "buen alumno", por su "mérito, aplicación, compostura, cortesía y camaradería". El dibujante Cabu toma como objeto de su mirada satírica la relación de subordinación del Jefe de Gobierno, quien a su parecer, se limitará a obedecer las órdenes del Presidente. En la Figura 1b, el desfile de asunción de Carlos Menem es asociado con la llegada a la meta de un ciclista. De esta manera se hace alusión al aumento del precio de la gasolina, en el marco de un ajuste económico impulsado para hacer frente a la crisis argentina de 1989.

Figura 1 a y b

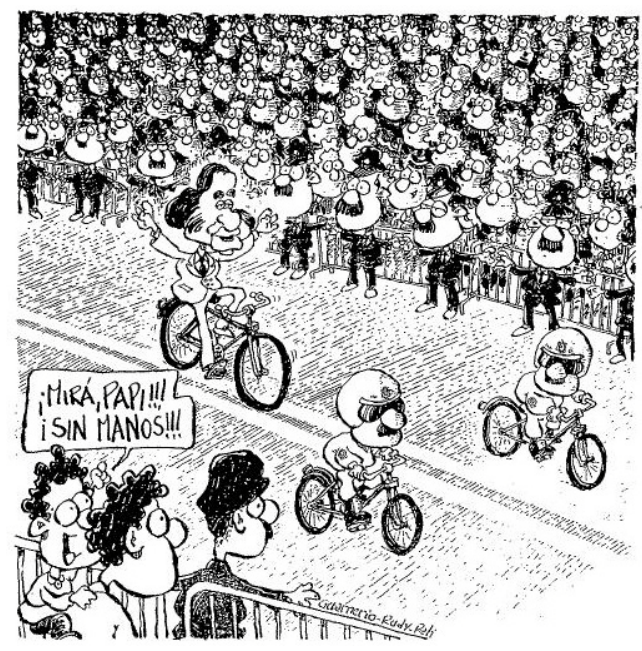

Fonte: Pati, (1989, p. 2.)

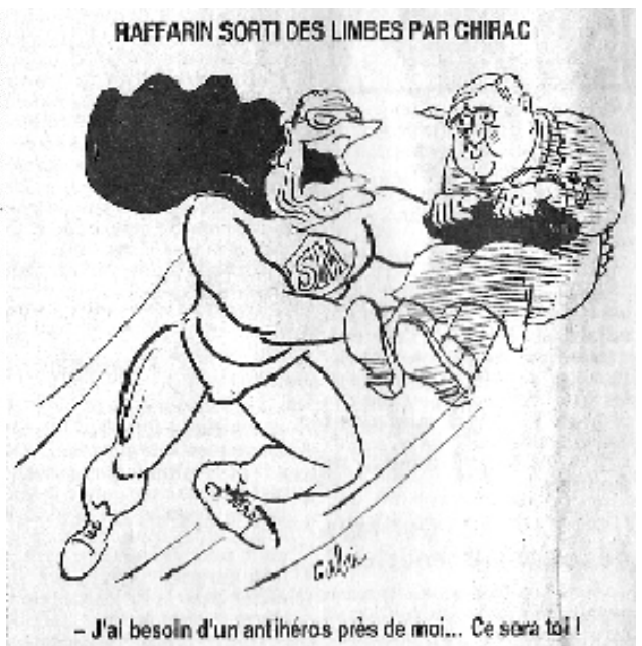

Fonte: Cabu, (1995, p. 1)

El alto número de metáforas identificadas en el corpus no es casual si pensamos en ella, junto a Catherine Fromilhague, como "una figura ejemplar, prototípica de las demás, porque es potencialmente capaz de cumplir todas las funciones de las cuales puede estar investida una 
figura" (FROMILHAGUE, 1995, p. 88) ${ }^{8}$ y que se reducen en las tres reglas antes señaladas: atraer, emocionar e instruir. Las metáforas solicitan la capacidad interpretativa del lector, al desafiarlo a encontrar la relación entre comparado (en la Figura 1a, Alain Juppé) y comparando (referente virtual: buen alumno), o a descubrir cuál es el comparado ausente. Por otro lado, el hecho de asociar inusualmente dos ideas, esto es, de hacer que el lector transfiera al comparado tal comparando, es una estrategia argumentativa de gran fuerza persuasiva, ya que el receptor debe, aunque sea por un momento, anular el conflicto conceptual y aceptar dicha asociación para poder interpretar el mensaje.

Dentro de las figuras de pensamiento, la hipérbole, la figura de la exageración por excelencia, es la más utilizada en ambos corpus, seguida por la alusión, sobre la cual volveremos más abajo. La hipérbole que consideramos en nuestros análisis es aquella que se aplica a situaciones, como es el caso de la Figura 2a, en la que la participación de Carlos Menem en un partido de fútbol con fines solidarios es llevada a un extremo. Del grupo que reúne las metáforas fijas y el símbolo, éste último reúne el porcentaje más alto. Se trata de un recurso de gran utilidad para condensar sintéticamente - a través de un signo- una idea abstracta, consensuada culturalmente, tal el caso de los signos religiosos o bien de las cacerolas de la Figura $2 \mathrm{~b}$, que en el patrimonio verbal y visual francés hacen referencia a casos de corrupción. Golpeando una de las tantas cacerolas colgadas, Jacques Chirac dice: "iCon todas las cacerolas que tenemos, hay que llenarlas bien!".

\section{Figura 2 a y b}

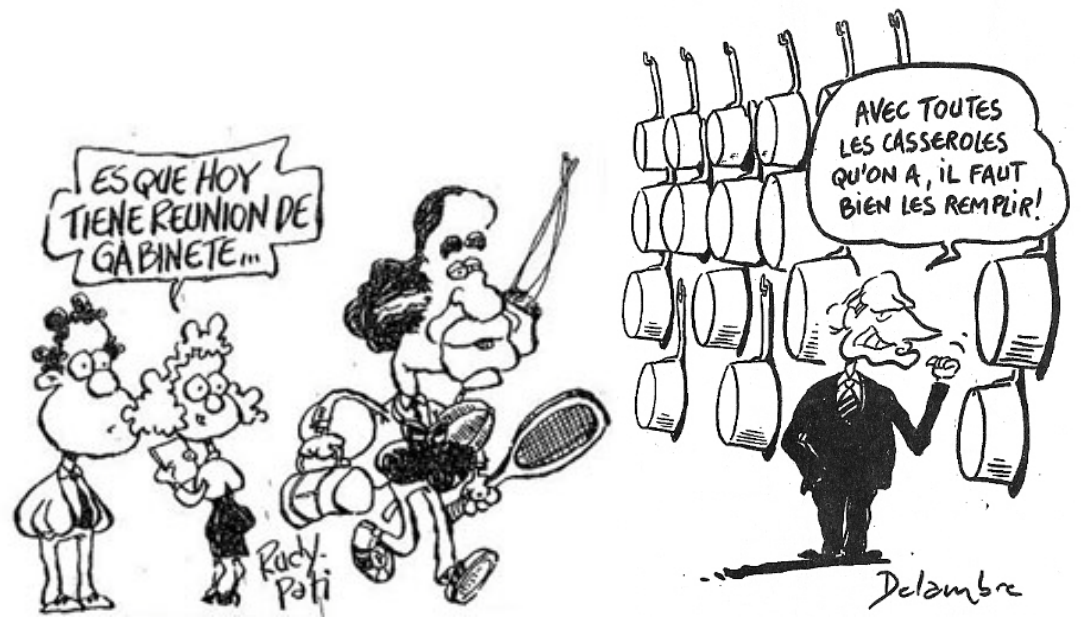

Fonte: Rudy y Pati, (1989, p. 3.) Fonte: Delambre, 10/04/2002, p. 3.

\footnotetext{
${ }^{8}$ Cita original: "une figure exemplaire, prototypique des autres, parce qu'elle est potentiellement capable de remplir toutes les fonctions dont une figure peut être investie".
} 
Figura 3 - Figuras retóricas ícono-plásticas más recurrentes en los corpus constituidos por las caricaturas políticas del Canard enchaîné y Sátira/12.

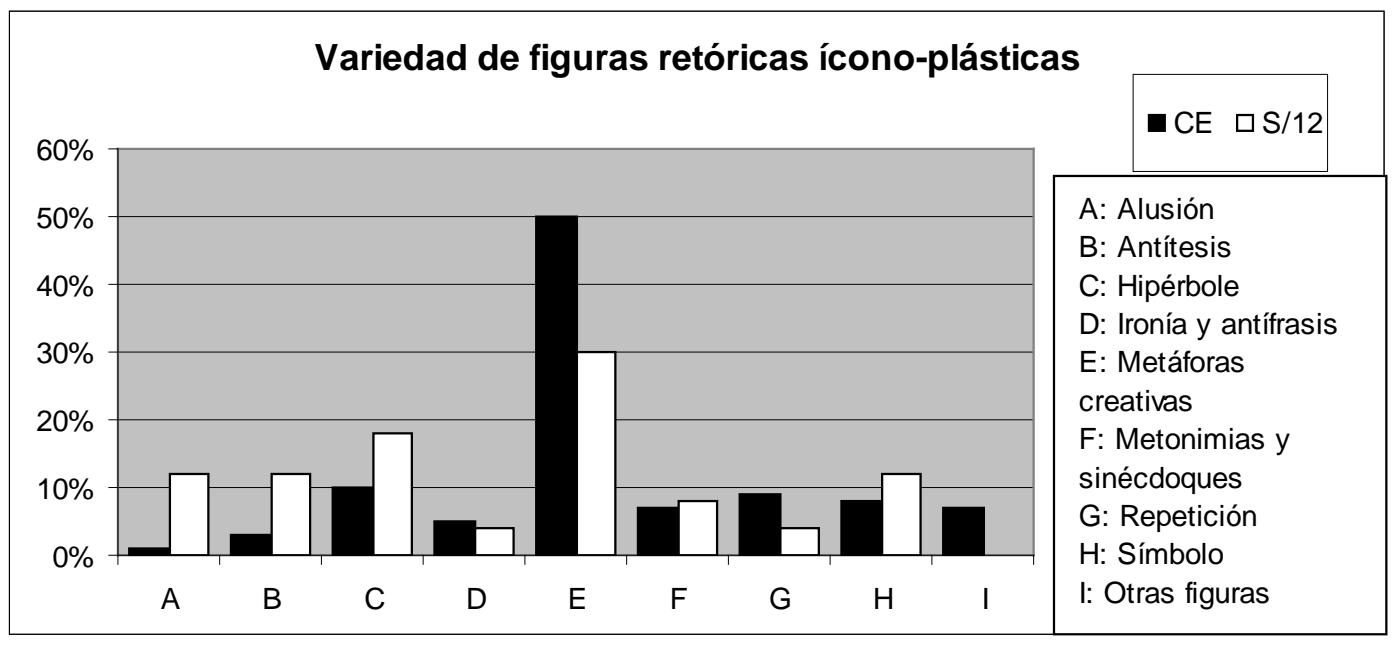

Entre las figuras de construcción, la antítesis y la repetición son las más habituales mientras que los grupos menos numerosos de figuras visuales están conformados por la ironía y sus variantes y por las figuras de doble sentido, mucho más explotadas en lo verbal.

En el caso de las figuras retóricas lingüísticas identificadas en ambos periódicos, no se observan grandes diferencias en la distribución de los grupos (sólo en las figuras de pensamiento, según puede apreciarse en la Tabla 2) ni tampoco, salvo contadas excepciones, en las figuras más recurrentes, que se reducen a una decena (Figura 4). Lo que varía, en algunas ocasiones, es el grado de importancia que cada figura tiene con respecto a las demás. Para identificar en qué figuras específicas residen las diferencias, realizamos el cálculo del residual estandarizado sobre la variedad de figuras lingüísticas. Sólo tres categorías de las trece consideradas se diferencian estadísticamente. Analizaremos esos casos para luego detenernos en otras de las figuras más numerosas de uno y otro periódico.

La diferencia más notable es el uso de la alusión -dentro de las figuras de pensamientopor parte de Sátira/12. La misma está presente en una de cada tres caricaturas, contra una proporción de una de cada diez en Le Canard enchaîné. A través de esta figura, se propone un juego al lector, quien debe descubrir el sentido oculto, vehiculizado a través de aquellas "referencias implícitas y oblicuas a un elemento exterior al universo del enunciado" (FROMILHAGUE, 1995, p. 117). Un ejemplo de este recurso es el ya mencionado en la Figura $1 \mathrm{~b}$. 
Figura 4 - Figuras retóricas lingüísticas más recurrentes en los corpus constituidos por las caricaturas políticas del Canard enchaîné y Sátira/12.

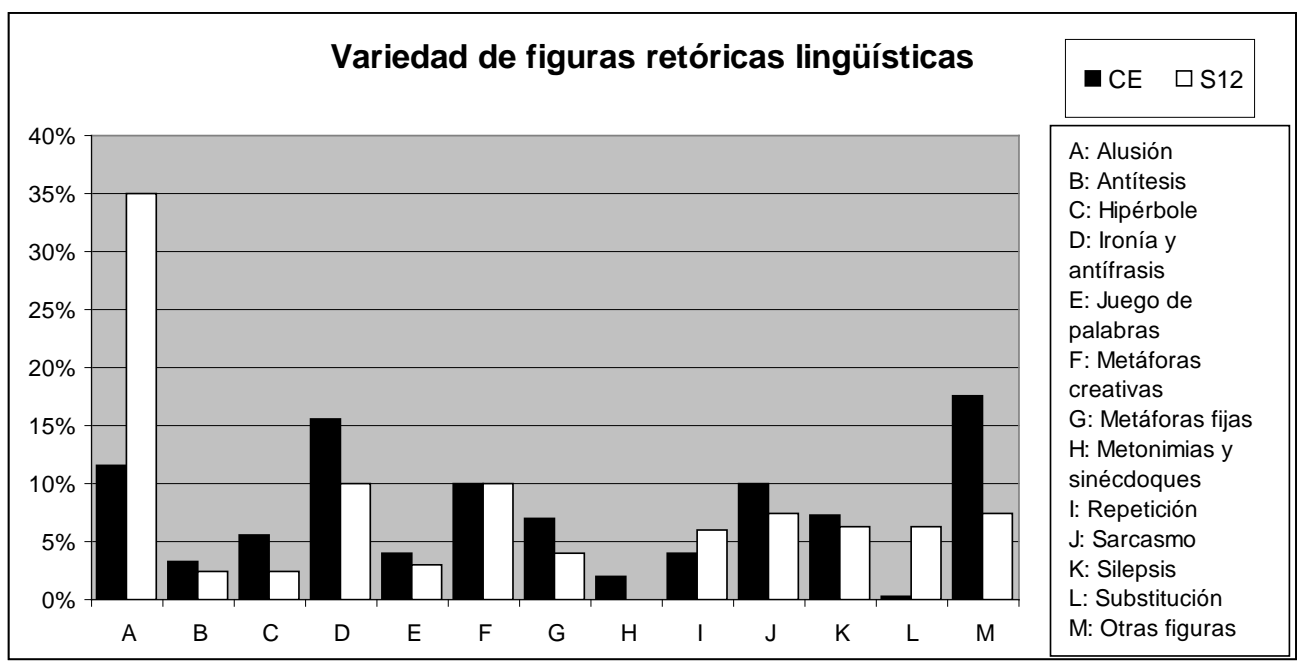

Un segundo caso en el que las diferencias son estadísticamente significativas radica en otra figura de pensamiento que se destaca en el periódico argentino, la substitución, que rompe con las frases hechas o familiares al reemplazar una o más palabras por otras que sorprenden y por ende, divierten. En la Figura 5a, un asesor sugiere a Carlos Menem la firma de un decreto en el que se deslinde de responsabilidades a su gobierno de la crisis social, política y económica que atravesó la Argentina en 1989 y que llevó al Presidente Raúl Alfonsín (1983-1989), del partido radical, a adelantar el traspaso de poder por unos meses (julio en vez de diciembre). La substitución se observa en la alteración de dos fórmulas lingüísticas características del ámbito jurídico: "todo lo que ud diga podrá ser usado en su contra" y "sanciónese, archívese, guárdese”. El verbo "síganme" hace alusión al slogan de campaña de Carlos Menem: "síganme, no los voy a defraudar". La caricatura de Rudy y Paz no sólo es una crítica hacia las medidas tomadas para enfrentar la crisis sino también una ridiculización sobre el número de decretos de excepción considerado excesivo por los autores- que el gobierno de Menem llevaba firmados a dos meses de haber asumido. En este sentido, la caricatura de Rudy y Paz captó rápidamente una de las facetas más conocidas del gobierno menemista, caracterizado por algunos como un "gobierno por decreto" (FERREIRA RUBIO; GORETTI, 1994 apud BONNET, 2007).

El tercer caso de diferenciación entre Sátira/12 y Le Canard enchaîné es el de la categoría otras figuras, que reúne los distintos tipos de figuras identificados con baja frecuencia. El 
semanario francés se distingue por presentar una mayor variedad de figuras verbales como el calambur, dentro de las figuras de sentido, sello de fábrica de sus títulos; figuras de palabras como el acrónimo (mot-valise) y el apócope; figuras de construcción como la anáfora y la derivación; entre otras.

La figura más habitual en este periódico es la ironía y su variante más específica, la antífrasis. La ironía ha sido habitualmente definida como lo contrario a lo que uno quiere dar a entender, dando lugar a un desfase entre el sentido aparente y el sentido oculto. El uso más amplio que se ha hecho de este término hizo que su significado se extienda para comprender no sólo "lo contrario" sino también "otra cosa" de aquello en lo que piensa el locutor. La ironía se alejaría así de la antífrasis, que quedaría más anclada a una especificidad semántica de oposición (KERBRAT-ORECCHIONI, 1980). En este sentido, la distinción efectuada por Georges Molinié entre figura microestructural y macroestructural es muy operacional ya que si la antífrasis puede ser aislada y fácilmente identificable a partir de ciertos indicios, la ironía adquiere un status más global y difícilmente aislable.

La ironía se funda sobre la contraposición de dos puntos de vista antagonistas: el autor simula adoptar el discurso adverso en su propia enunciación, al mismo tiempo que toma distancia implícitamente de él para ridiculizarlo y desautorizarlo. Esta estrategia de descalificación es puesta en práctica a partir de diferentes procedimientos, entre los cuales el hecho de sacar de contexto una cita o una acción es muy recurrente en la prensa satírica. A continuación daremos ejemplos de ambas figuras para clarificar su diferenciación.

La Figura $5 \mathrm{~b}$ fue publicada luego de que Jacques Chirac decidiera, apenas iniciado su mandato en 1995, retomar la última serie de ensayos nucleares antes de firmar en 1996 el Tratado de Prohibición Completa de Ensayos Nucleares. Identificamos aquí una paradoja antifrástica puesto que el título "El mundo entero ha entendido que..." introduce una opinión común que sin embargo "choca" con la justificación contradictoria del personaje: "Si retomamos los ensayos nucleares, es para pararlos mejor después". Por otro lado, Jacques Chirac se encuentra vestido con el uniforme de Charles de Gaulle (metáfora visual), lo cual puede explicarse por dos razones por lo menos: por un lado, Jacques Chirac es considerado continuador del modelo gaullista, por otro lado, durante la Presidencia de de Gaulle (1959-1969) se llevaron a cabo numerosos ensayos nucleares. 


\section{Figura 5 a y b}

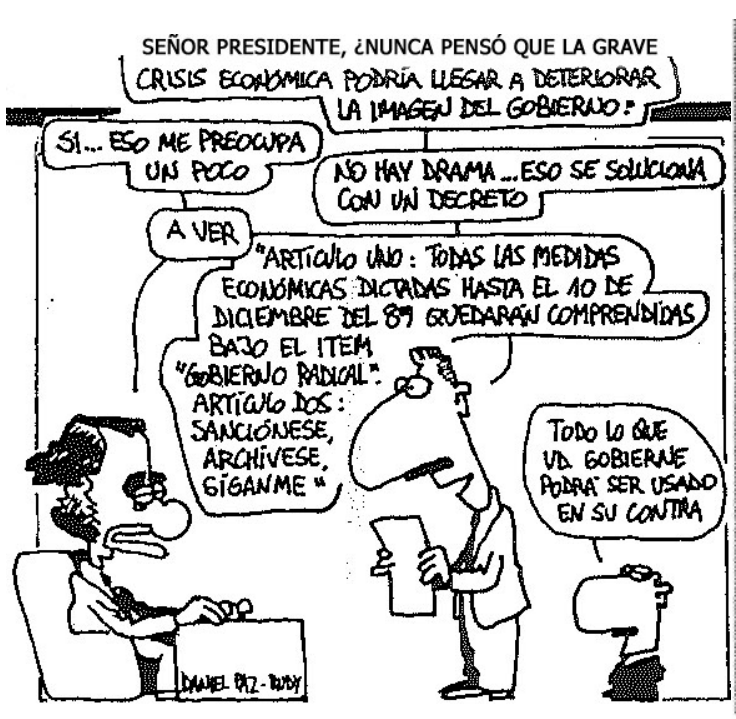

Fonte: Rudy y Paz, (1989, p. 1)

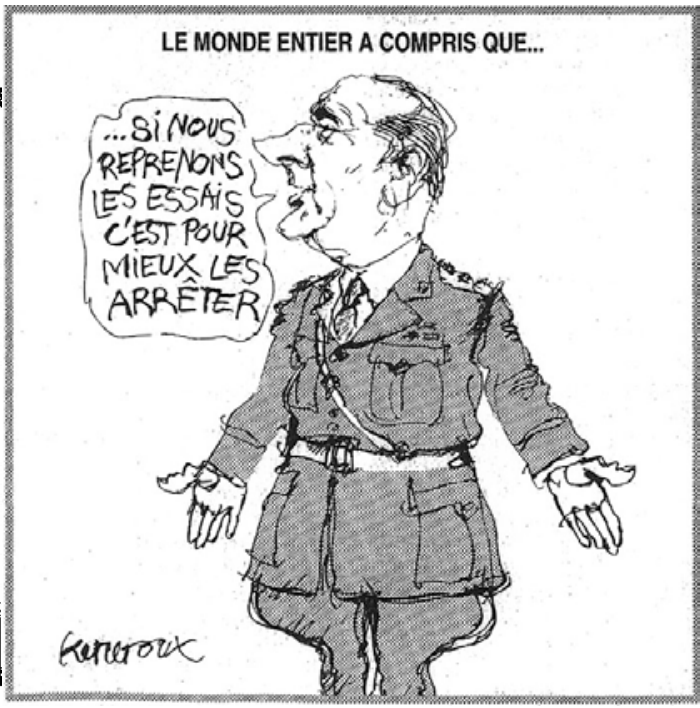

Fonte: Kerleroux, (1995, p. 2)

En la Figura 6a, el dibujante Cardon asocia dos de las primeras acciones efectuadas por Jacques Chirac en 1995: visitar la tumba de Charles de Gaulle en Colombey-les-Deux-Églises y dejar un ramo con los tres colores de la bandera francesa, por un lado, e impedir a los autos de altos funcionarios pasar los semáforos en rojo como se hacía hasta el momento, por otro. La caricatura es rica en figuras retóricas. En primer lugar, el ramo es substituido por dos semáforos, cuyos colores -si bien no son los mismos pero son tres- remiten metonímicamente a la bandera de Francia. También se hace uso de una metáfora al establecer una analogía -por la forma y por el carácter tricolor- entre el ramo (comparado presente en el título de la imagen) y el semáforo (comparando). Por último, el título nos sirve de ejemplo de ironía pues saca de contexto, tornando absurdas, las dos acciones antes mencionadas: "El gaullismo, es el respeto de los semáforos. Depósito de un ramo en Colombey". Esta frase implica una fuerte crítica hacia la primer medida tomada por Jacques Chirac (referente a los semáforos), que buscaba estar en sintonía con la imagen de modestia que el gobierno intentaba dar. A partir de ésta y otras caricaturas y notas, Le Canard enchaîné dio a entender que consideraba banal esta primera medida, la cual no juzgaba acorde con el modelo gaullista del cual el Presidente se declaraba heredero.

Cabe destacar que la referencia a Charles de Gaulle se usa con frecuencia asociada al personaje Chirac, aún con fines opuestos, según el acontecimiento tratado: ya sea para marcar las 
diferencias (Figura 6a) o bien las semejanzas (Figura 5b) entre ambos políticos, pero siempre desde una perspectiva crítica.

Pasemos ahora al caso de las metáforas. Ambos periódicos hacen igual uso de las metáforas creativas, siendo un poco más marcada la diferencia con las metáforas fijas, más recurrentes en el semanario francés. Contrariamente a las primeras, éstas han sido banalizadas por el uso, es decir que se trata de expresiones figuradas que se han cristalizado. El periódico puede optar por ellas por la familiaridad que producen en el lector, aunque muchas veces están revestidas de una finalidad satírica. Así, en la Figura 6b, Jacques Chirac tiene una hoja donde está escribiendo los nombres del gobierno de su Primer Ministro Jean-Pierre Raffarin (2002-2005), luego de la reelección presidencial. A su costado se encuentra su ex Primer Ministro Alain Juppé (1995-1997) y un poco más alejado, el Jefe de Gobierno Raffarin. Chirac exclama: "Un solo juez pisándonos los talones, ¿creen ustedes realmente que eso nos impide gobernar?" La expresión avoir les juges aux fesses (tener a los jueces pisándote los talones) vehiculiza dos ideas diferentes sin duda puede haber otras. La más evidente hace referencia a posibles casos de corrupción que involucrarían a los políticos del círculo de Chirac. Una lítote refuerza el sentido por una vía indirecta, a través del adverbio "un solo juez", diciendo menos de lo que en realidad quiere darse a entender. La otra idea movilizada presenta al Presidente como alguien que se expresa familiar y hasta vulgarmente en su círculo privado (fesses significa trasero), sentido recurrente en Le Canard enchaîné.

\section{Figura 6 a y b}

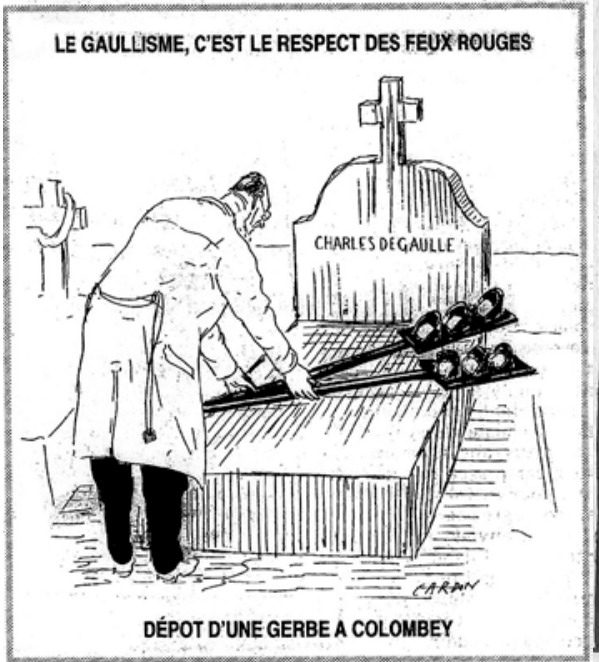

Fonte: Cardon, (1995, p. 4)

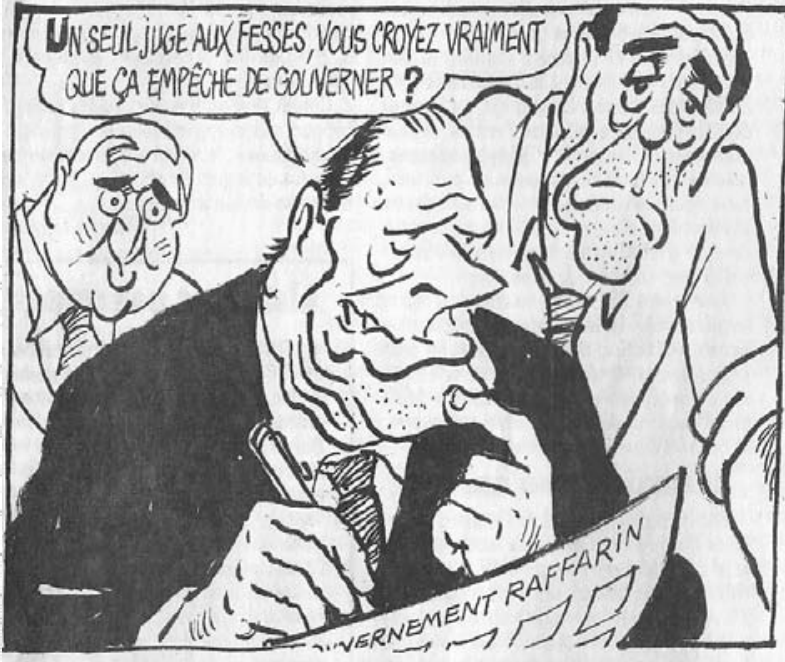

Fonte: Cabu, (2002, p. 3) 
De las figuras de construcción, la antítesis y la repetición son las más habituales en ambos corpus, mientras que de las figuras de sentido se destacan los juegos de palabras y la silepsis. Esta última se produce cuando a un mismo signo corresponden dos significados diferentes, en general uno propio y otro figurado, aunque no necesariamente, como por ejemplo en una caricatura en la que se representa a Carlos Menem jugando al fútbol y un hincha le grita "Buscá el centro" y otro le responde: "Callate liberal".

Hemos visto algunas de las figuras retóricas más explotadas por dibujantes y guionistas de uno y otro periódico. A modo de síntesis podría decirse que Le Canard enchaîné presenta una mayor riqueza de recursos, tanto visuales como verbales. Su humor se destaca por el uso de metáforas creativas en lo visual, a partir de las cuales los autores establecen analogías inesperadas, apelando en ocasiones a la construcción de situaciones ficticias. En lo verbal el semanario juega con lo implícito, ya sea a través de alusiones y fundamentalmente de la ironía y sus variantes; opta por la familiaridad de expresiones que pone en boca de los políticos mediante las metáforas fijas; juega con las palabras y el doble sentido. Sátira/12 se destaca por el uso de las figuras de pensamiento, en particular de la hipérbola en lo visual, la substitución en lo verbal, la alusión en ambos lenguajes. De esta manera, apela con mayor frecuencia a procedimientos discursivos que incorporan de forma muy recurrente elementos extratextuales, a menudo referencias culturales relacionadas con la historia del país, productos de la industria mediática o los deportes.

\section{Conclusiones}

El aparato teórico-metodológico elaborado nos permitió analizar el comportamiento de las distintas dimensiones y categorías consideradas, que se interesan en: los personajes que los autores satíricos representan en las caricaturas políticas, la forma de representar gráficamente la figura presidencial de Carlos Menem y Jacques Chirac y las distintas figuras retóricas lingüísticas e ícono-plásticas utilizadas.

Las dimensiones formales presentaron, en general, una distribución similar en los periódicos Le Canard enchaîné y Sátira/12. En la mayoría de las caricaturas, Carlos Menem y Jacques Chirac son dibujados en su función presidencial: con gestos formales, trabajando de pie, en traje, corbata y camisa, y serios. Comparativamente, el estilo de los autores de Sátira/12 está 
más anclado en lo real, siendo prácticamente inexistentes los casos en los que se opta por situaciones fantasiosas. El presidente argentino aparece a veces dibujado como un jugador de fútbol, pero considerando su participación real en este tipo de eventos deportivos, no puede hablarse verdaderamente de ficción o fantasía.

La representación tan próxima que los autores de ambas publicaciones satíricas hacen de los personajes presidenciales es llamativa, considerando que se trata de dos personalidades políticas diferentes y de dos corpus distantes lingüística, geográfica e históricamente. Estos hombres son principalmente dibujados en su función pública, en contextos y comportamientos esperados. Este resultado merece ser testeado en investigaciones futuras pues nos inclinamos a pensar que la tendencia se mantendrá aún analizando otros Presidentes de Francia y Argentina y a lo mejor incluso en otros países.

El estudio pormenorizado de las figuras retóricas nos permitió ver que las figuras íconoplásticas son mucho menos habituales y variadas que las figuras lingüísticas. Distintas razones pueden ser aquí evocadas para intentar dar luz sobre este fenómeno. En primer lugar, la existencia de un posible sesgo proveniente del hecho de que los estudios sobre la imagen se desarrollaron a partir de la transposición de conceptos y términos concebidos inicialmente para el lenguaje verbal. En este sentido, Fernande Saint-Martin (1987) postuló que en este proceso de transposición, aquellos elementos de base del signo visual que no podían ser nombrados, y por lo tanto decodificados a partir de lo verbal, fueron excluidos de una reflexión analítica. Sin duda esto pesa sobre las diversas clasificaciones de figuras retóricas existentes. Una segunda causa guarda relación con las características inherentes a los lenguajes verbal y visual (estructura lingüística lineal, co-presencia espacial de unidades ícono-plásticas, entre otras), que repercuten en una mayor dificultad tanto en la producción como en la recepción de mensajes visuales complejos. Esta razón puede estar asociada con el hecho de que los dibujantes opten por realizar caricaturas prescindiendo de elementos gráficos, claro que aquí también incide la celeridad con la que deben trabajar, además del espacio limitado -generalmente una viñeta- del que disponen.

El papel comparativamente reducido de las figuras ícono-plásticas en las caricaturas, sumado a la representación "conservadora" de la figura presidencial, sugieren que el juego satírico-humorístico no se funda tanto en el lenguaje visual. Esto está en sintonía con resultados de un estudio previo, en el que el análisis funcional y retórico de caricaturas políticas puso de manifiesto un predominio verbal, aún en este tipo de textos, en los que ambos lenguajes están estrechamente asociados (PEDRAZZINI; SCHEUER, 2010).

No encontramos grandes diferencias en cuanto a los distintos grupos de figuras íconoplásticas utilizados: las metáforas son los recursos más habituales, permitiendo generalmente asociar dos ideas insólitas o incongruentes que justamente por ello, resultan cómicas. En ocasiones se trata de dos hechos de actualidad que no guardan a priori relación. Este recurso es 
denominado por Patrick Charaudeau (2006) como "incoherencia insólita", dentro de los procedimientos lógicos que juegan con el aspecto semántico de los signos.

Las figuras retóricas lingüísticas detectadas en nuestro corpus son más variadas y numerosas. Las mayores diferencias detectadas entre los dos periódicos residen en los tipos de figuras identificados. Si bien las figuras que alcanzan los mayores porcentajes son básicamente las mismas en ambos periódicos, el peso de las mismas es lo que más varía. El discurso satíricohumorístico de las caricaturas de Sátira/12 podría ser calificado como el de las "indirectas" pues el sentido latente sólo puede emerger de forma oblicua a partir de la actualización de elementos extratextuales. Las caricaturas de Le Canard enchaîné, por su parte, presentan una mayor diversidad de figuras, entre las cuales las más recurrentes son la ironía y sus variantes, que operan fundamentalmente a partir de una oposición semántica. Tanto la alusión del suplemento argentino como la ironía del semanario francés pertenecen al grupo de figuras de pensamiento, que apelan al bagaje cultural del lector, quien debe reconocer referencias externas al universo del tema abordado, suponiendo entonces un desafío de interpretación mayor.

La identificación de una tendencia similar en gran parte de los recursos de ambas publicaciones satíricas brinda argumentos a favor de la existencia de un sistema de procedimientos visuales y verbales en común operando en la caricatura política. Sin duda una hipótesis para seguir testeando en nuevos corpus provenientes de éstos y otros países.

\section{Referencias}

BARTHES, Roland. Rhétorique de l'image. Communications, Paris, v. 1, n. 4, p. 40-51, 1964.

BERGSON, Henri. Le rire: essai sur la signification du comique. Paris: PUF, 1924.

BETH, Axelle; MARPEAU, Elsa. Figures de style. París: Librio Mémo, 2005.

BONNET, Alberto. La hegemonía menemista: el neoconservadurismo en Argentina, 1989-2001. Buenos Aires: Prometeo Libros, 2007.

CHARAUDEAU, Patrick. De nouvelles catégories pour l'humour? Questions de communication, Nancy, n. 10, p. 19-41, 2006.

DUPRAT, Annie. Les rois de papier: la caricature de Henri III à Louis XVI. Paris: Belin, 2002. 
DURAND, Jacques. Rhétorique et image publicitaire. Communications, Paris, v. 1, n. 15, p. 40-51, 1970.

ECO, Umberto. Apocalípticos e integrados. Buenos Aires: Tusquets, 2008.

FERNÁNDEZ, Manuel; VIVERO GARCÍA, María Dolores. L'humour dans la chronique de la presse quotidienne. Questions de communication, Nancy, n. 10, p. 81-102, 2006.

FROMILHAGUE, Catherine. Les figures de style. París: Nathan, 1995.

GOMBRICH, Ernst. The experiment of caricature. In: . Art and Illusion: a study in the Psychology of Pictorial Representation. Londres: Phaidon Press, 1984. p. 279-303.

GROUPE $\mu$. Traité du signe visuel: pour une rhétorique de l'image. París: Éditions du Seuil, 1992.

HOUDEBINE-GRAVAUD, Anne-Marie; POZAS, Mae. De l'humour dans les dessins de presse. Questions de communication, Nancy, n. 10, p. 43-64, 2006.

KERBRAT-ORECCHIONI, Catherine. L'ironie comme trope. Poétique, Paris: n. 41, p. 108-127, 1980.

MOLINIÉ, Georges. La stylistique. París: Presses Universitaires de France, 1993.

PEDRAZZINI, Ana; SCHEUER, Nora. La interacción lingüística e ícono-plástica en la producción de caricaturas políticas: un estudio funcional y retórico. IRICE Nueva época, Rosario, n. 21, p. 95-111, 2010 .

PEDRAZZINI, Ana. La crisis argentina del 2001 a través de las tapas de Página/12: un estudio semio-lingüístico centrado en la interacción texto-imagen. In: BIENAL IBEROAMERICANA DE COMUNICACIÓN, 6., 2007, Córdoba. Actas... Córdoba: Universidad Nacional de Córdoba, 2007.

QUEVEDO, L. A. Política, medios y cultura en la Argentina de fin de siglo. En : FILMUS, D. (Ed.). Los noventa. Política, sociedad y cultura en América Latina y Argentina de fin de siglo. Buenos Aires: EUDEBA-FLACSO, 1999.

REBOUL, Olivier. La rhétorique. París: Presses Universitaires de France, 1993.

ROBRIEUX, Jean-Jacques. Eléments de rhétorique et d'argumentation. París: Dunod, 1993.

SAINT-MARTIN, Fernande. Sémiologie du langage visuel. Québec: Presses de l'Université du Québec, 1987.

SEURRAT, Aude. La mise au jour des médiations à travers l'affaire des caricatures. Citations d'images. Communication \& Langages, Paris, n. 155, p. 27-38, 2008.

STEIMBERG, Oscar. Sobre algunos temas y problemas del análisis del humor gráfico. Signo y Seña, Buenos Aires, n. 12, p. 99-118, 2001.

TILLIER, Bertrand. A la charge! la caricature en France de 1789 à 2000. París: Les Editions de l'Amateur, 2005.

ULANOVSKY, Carlos. Paren las rotativas. Buenos Aires: Espasa, 1997. 


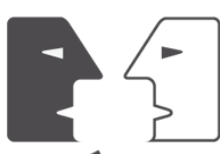

ANTÍTESES

VILCHES, Lorenzo. La lectura de la imagen: prensa, cine, televisión. Barcelona: Paidós, 1984.

ZIV, Avner. National styles of humour. New York: Greenwood press, 1988.

Recebido em 30/02/2012

Aprovado em 30/05/2012 